\title{
Discussion on Problems Existing in Tourism Management
}

\author{
Major Construction \\ Jing Cheng \\ School of International Economic and Trade, Xi' an International \\ University, Xi’an, 710077, China
}

\begin{abstract}
With the rise of China's tourism economy, while people are satisfied with material life, they are more wild about the travel and leisure so as to get more knowledge of local culture while they appreciate beautiful scenery in different regions. On this basis, the market-oriented operation of tourism is continuously quickened, which promotes the prosperous development of tourism market. There are also more and more demand for professional tourism talents; meanwhile, in order to adapt to the demand of tourism market, a higher requirement is proposed for tourism talents' quality. However, currently, the discipline construction of tourism management major is still lagging and it is hard for tourism education to adapt to the ever-changing development. This paper carries out a research on problems existing in tourism management major construction.
\end{abstract}

Key words: tourism management major; curriculum reform; problems; rationality

The tourism is the new growth point which drives social and economic development. With strong competition in tourism market, it is required to improve tourism practitioners' quality so as to realize bigger and stronger tourism. China's current development of tourism economy mainly depends on development and utilization of rich regional resources, which seriously damages the integrity of natural resources. In recent years, various countries in the world advocate ecological environmental protection and green ecology; in terms of development of tourism resources, China shall improve the availability of limited resources on the protection basis. The new concept will cause new lifestyle, which will certainly cause change in people's way of 
thinking. The tourism has become China's leisure fashion at present; however, with the change of tourism concept, there shall be corresponding adjustment in discipline construction of tourism management so that the talents cultivated can be more capable of tourist industry and strongly face the competition in tourism market.

\section{Current situation of China's tourism management major construction}

(I) The tourism management major construction has strong locality.

In terms of China tourism practitioners' quality, the personnel quality is low, which seriously influences the competitiveness of China tourism. In order to obtain a long-term development, the attention shall be paid to cultivation of tourism talents. According to the cultivation situation of tourism talents in Chinese universities, based on regional features of tourism, the talent cultivation shall adapt to the cultivation direction of regional tourism development, and more attention shall be paid to students' professional cultivation, which is of great practical significance. From the perspective of employment, after the students majoring in tourism graduate, they can step into tourist industry to take a job, and the practical cultivation can further mitigate students' employment pressure and improve their competitiveness in tourism market. However, from long-term perspective, the tourism management talents' quality shall be improved while those talents continuously adapt to tourism competition, and the pure practical cultivation can't meet the sustainable development demand of tourism.

(II) The talent cultivation of tourism management major is not systematic.

Through overview on tourism management major construction of Chinese universities, those universities have cultivated large quantity of tourism talents for Chinese development of tourism economy since China's reform and opening-up policy. After the $21^{\text {st }}$ century, China makes some adjustment in the policies for development of tourism economy; besides, with the proposal of the development and guiding thought of further deepening reform and opening-up in the $3^{\text {rd }}$ Plenary Session of $18^{\text {th }}$ CPC Central Committee, the universities pay more attention to tourism management major construction. However, due to late starting of tourism management major in universities, the discipline construction of this major takes reference from other 
disciplines and it is developed into multiple cultivation levels, which causes not systematic discipline construction. Besides, the regional cultivation trend for tourism talents causes large regional gap in tourism management major in different regions.

(III) The curriculum provision of tourism management major influences its own development direction.

At the beginning of construction, the tourism management major belongs to management discipline in universities and it exists as an independent second-level discipline. In the end of $20^{\text {th }}$ century, through adjustment, the tourist economy, as a discipline of economics, is included into tourism management major. The attribute adjustment highlights the difference between tourism management and tourism economy, which causes serious influence on development of tourism discipline.

The development of Chinese tourism drives the rise of tourism education. More and more students start from active development prospect of tourism market and select the tourism management major, thus meeting the demand of tourism talent market. However, in terms of curriculum provision of tourism management major, in 1980s, China's economy forms a condition of rapid development and the talent demand exceeds the supply, thus the tourism talents are short and there is low talent quality requirement. With rapid and stable development of China's economy, more and more students witness the rise of Chinese tourism, and they aim at tourism and join the learning in tourism major. However, according to the condition of Chinese higher tourism education, most of universities don't have independent setting of tourism major, but attach this major to relevant discipline, such as School of Economics and Management, School of Literature, and School of Foreign Languages; due to different initial education environment, the tourism discipline also has different development, which causes a weak basic research of tourism discipline.

\section{Problems existing in tourism management major construction}

(I) The tourism management major has a not accurate positioning.

The reason why some universities set a tourism management major is that they are affected by development trend of China's tourism economy to recruit students based on the rise of regional tourism, without formulating clear cultivation goal for students 
majoring in tourism management. There exists certain relation between tourism management major construction and department leaders. As for tourism major leaders of partial universities, the functional value of tourism management major is to cultivate professional talents for tourism enterprises and mainly focus on people-to-people diplomacy, and they think that the leaders of tourism units shall bear the practical cultivation responsibility as for the development of tourism resources and operation of tourism enterprises. From perspective of discipline education, the tourism management major belongs to integrated discipline; in case of one-sided professional cultivation goal, the students majoring this major shall be neither capable of future position nor capable of improving their work ability with tourism development, thus it is hard for them to become the managers who adapt to tourism development requirements.

(II) The cultivation content of tourism management major teaching is not practical.

There exists hierarchy in China's tourism talent cultivation, and the tourism major is set in technical secondary schools, junior colleges, undergraduate and postgraduate education. From perspective of this discipline, China has carried out a systematic teaching on tourism major; however, from perspective of talent cultivation, the talent cultivation content is not practical. The tourism management major education of technical secondary schools and junior colleges develops towards undergraduate education and attempts to improve professional teaching level; the undergraduate and postgraduate education excessively emphasize theory and research, thus they gradually transfer to tourism practical talents; under this condition, the misplaced tourism management talent cultivation appears and this problem has become the main problem which shall be solved in tourism management major construction. As for the assessment on the professional ability of current graduates graduating from tourism management major, the relevant tourism departments think: "When they talk about something, it seems that they are well learned; however, when they make practice, they are at a loss.” Some graduates graduating from tourism major are excessively idealistic to their work, and they think that the tourism not only has low work efficiency, but also lacks of flexibility under the influence of social environment, 
which is greatly different from modern tourism, thus they lose confidence on the development of Chinese tourism. Besides, although some students have learnt lots of relevant knowledge, it is hard for them to effectively exert the knowledge in practice work. The professional tourism talents cultivated in universities can't adapt to the demand of tourism development, which can be called the failure of tourism education, thus it remains to formulate effective teaching improvement strategy.

(III) The tourism management majors don’t establish a cooperative relationship with tourism units.

The tourism management majors of universities bear the responsibility of cultivating talents for local tourism; however, instead of being limited to short-term talent demand, they shall cultivate talents from perspective of future tourism development. Therefore, the colleges and universities shall be forward-looking in the setting of curriculum content of tourism major. In order to make the knowledge structure of tourism major adapt to tourism development and make the cultivated tourism talents more adapt to tourism development demand, the relevant leaders of tourism major shall establish a cooperative relationship with tourism units so as to make cultivation direction of tourism talents consistent with tourism market direction. However, through analysis on employment difficulty of tourism talents, it can be found that it is the derailment between school running and tourism that results in the situation that the tourism talents cultivated in universities suffer employment difficulty. With common application of university-enterprise cooperation teaching mode, some universities have established a cooperative relationship with some enterprises from perspective of students' internship; however, their cooperation is only limited to providing internship unit, without establishing long-term cooperative relationship; in this way, the teaching result of tourism major is only limited to school education and not approved by business circle.

\section{Basic thoughts on reform of tourism management major}

(I) The tourism management major shall enhance teaching staff construction.

In order to realize teaching technology of tourism management major, to optimize the teaching staff is the concept. The tourism education is an emerging industry which 
appears with China's economic development; in order for high practical skills, the rich theoretical knowledge is required as support; besides, the tourism education will change with social development.

In terms of current teacher structure of tourism management majors in universities, most of old teachers are transferred from other discipline; most of middle-aged and young teachers are college graduates and lacks of practical experience. In order to mitigate the boring teaching environment of tourism management major, it is required to adjust the teacher structure. Firstly, it is required to change traditional way of teacher structure in thought aspect and adjust teaching staff from students' perspective. The teaching and cultivation shall be combined: on one hand, it is required to encourage young teachers to participate in local tour guide team to accumulate practical experience; on the other hand, the tourism teaching can be transferred from classroom to tourist attractions to let students accept tourism teaching content in the practical environment, which not only can stimulate students' learning interest, but also can early position their career, determine their learning objective, exert their knowledge ability from perspective of interest, and train their skills to improve their employment competitiveness.

Then, the schools shall create conditions for teachers of tourism management major, and encourage teachers to comprehensively improve their comprehensive ability; employ off-campus famous persons to give lectures in schools so that the teachers of tourism major can have a chance to know industrial information and fully communicate with experts and scholars. Besides, it is able to actively carry out survey activities and enhance information construction; in this way, even though the teachers keep indoors, they can still have a chance to share information resources with others via network to promote their improvement in teaching and research ability. Through inviting relevant persons of tourism units to communicate with teachers of tourism major on relevant topics, the in-campus teachers can enrich their professional knowledge via absorbing others' practical experience, and the persons of tourism industry can also get some knowledge of professional tourism research, which is good for tourism development. 
(II) The tourism management majors shall pay attention to cultivation of students' practical ability.

China's tourism economy is just under prosperous development, thus there is large demand for professional talents and higher requirement for talent quality. In terms of talent cultivation, the tourism management major shall be inclined to students' skill teaching and carry out systematic teaching. Therefore, in terms of tourism talent cultivation, it is required to combine with local tourism development demand to realize the purpose of applying the knowledge. Due to rapid development, the tourism also shows a trend of diversified development and integrates multi-culture, thus there shall be a high sensitivity to tourism talent market in terms of education ability of tourism management major so as to timely adjust education scheme. The education shall be not limited to tourism skills, but combine with multiple disciplines to enrich students' cultural quality and improve students' creativity so as to cultivate high-quality comprehensive tourism talents. Besides, it is required to encourage the tourism management majors of universities to carry out joint operation with local tourism so as to let students engage in some tourism services upon providing them with internship condition, improve students' occupational skills, and also provide a chance for tourism industry to know professional talents' comprehensive quality.

\section{Conclusion}

In a word, China is just under rapid development of tourism industry, thus it is in short of tourism management talents, which provides more employment chances for tourism management professional talents. However, currently, there still exists the problem that the tourism talents face large employment pressure. From perspective of tourism major construction, in order to adapt to the requirements of tourism market, to continuously adjust and perfect tourism management major construction is an effective means to promote professional development.

\section{References}

[1] Wang Jinchao, Wei Fengyun: Research on Problems Existing in Undergraduate Practical Teaching of Tourism Management Major and Countermeasures [J], Journal 
of Changchun Teachers College (Natural Science), 2009. 28 (01).

[2] Shen Xiuying, Yang Qingwang: Problems Existing in Curriculum System of Tourism Management Major and Improvement Ideas [J], Journal of Hengyang Normal University, 2006.27 (02).

[3] Lam T, Xiao H. Challenges and constraints of hospitality and tourism education in China $[\mathrm{J}]$. International Journal of Contemporary Hospitality Management, 2006 (12).

[4] Girl Jogaratnam, Ken Mccleary, Miguela Mena, Joanne JunEunYoo. An analysis of hospitality and tourism research: institutional contributions [J]. Journal of Hospitality \& Tourism Research, 2005. 29 (03).

[5] Marion Stuart-Hoyle. The Purpose Of Undergraduate Tourism Programmers in the United Kingdom $[\mathrm{J}]$. Journal of Hospitality, Leisure, Sport and Tourism Education, 2003.2(01). 